\title{
GREEN BUSINESS PARKS TOWARDS SUSTAINABLE CITIES
}

\author{
SARA MOHAMED ATWA ${ }^{1}$, MONA GAMAL IBRAHIM ${ }^{1} \&$ AHMED MOHAMED SALEH $^{2}$ \\ ${ }^{1}$ Environmental Engineering Department, Egypt-Japan University of Science and Technology (E-JUST), Egypt \\ ${ }^{2}$ Architecture and Urban Planning Department, Suez Canal University (SCU), Egypt
}

\begin{abstract}
The world cities have an increasing task to provide a convenient habitat for most of the world's human population. Cities are generally responsible for most of the global carbon emissions. The sustainability concept has continued to be a top priority on the governmental agenda across the world. Business parks are designed to be environmentally sustainable, which will help reduce air pollution and develop social health and lifestyle. Besides many ecological and environmental services, business parks provide significant social and spiritual benefits to human societies. Green business parks aim to decrease the huge negative effect of business on both nature and society. The main purpose of this paper is to address the importance of green business parks for employees' and users' well-being, and for the sustainability of the city they inhabit. The paper introduces an evaluative framework for the sustainability of green business parks in Egypt. Therefore, the paper discusses the idea of the sustainable city and the connection between human well-being and the constructed environment in business parks. It also studies some cases that have appeared in the Egyptian cities; to show whether they achieve the aspects of sustainability or need redesign and upgrading plans. The study shows a concrete relationship between the indoor environment of business parks and human well-being. This endorses the fact that the more sustainable the place of work, the less its tendency to impose bad health effects on the building's occupants. Highlighting the important role of green business parks for employees' well-being and for a healthy environment can be a step towards future sustainable green cities in Egypt.
\end{abstract}

Keywords: skyscrapers, sustainable city, quality of life, business parks.

\section{INTRODUCTION}

The renaissance of countries depends on their economy; which confirms the need for the convenient office buildings. Such buildings appeared more than 100 years ago, they have been subjected to a lot of developmental stages influenced by subsequent technological changes. The increasing demand for wider offices has necessitated the need for higher buildings, which causes negative impacts on both the ecological balance and demographical balance. The environmental aspects should be highly reconsidered to ensure the convenience comfort and of the work place to let the workers get the best possible results. Buildings are responsible for the most carbon emissions, followed by transportation and industry. It is estimated that constructions in the Middle East consume 20-25\% of primary energy use, $40-45 \%$ of electricity consumption and $20-25 \%$ of carbon emissions [1]. The significance of business parks, a collection of similar architecturally arranged office buildings designed within a large green landscaped area, has recently appeared all over the world. These areas are usually situated outside the city-centre where land cost is cheaper and the city pollution is much less. Business parks have positive effects on employees ' health and wellbeing since they provide relaxation, save time and effort, minimize noise pollution, create safe places for work. The green business parks reduce the need for energy resources, natural resources, and fresh water while waste products can be recycled; which results in a significant reduction of operational costs and reduces the adverse effects on the environment and human health. It is clear that green business parks contribute a lot to achieving sustainability aspects and they can be considered a step towards creating sustainable cities. Business parks have recently 
appeared in Egypt to provide comfortable and healthy workplaces and encourage creativity and productivity. The paper shows the sustainability techniques used in certified successful green business parks in UK, Canada, Australia, China, Poland, and Netherlands. The result is a checklist of sustainable design methods that should be applied on the actually designed business parks, so as to redesign or upgrade plans to achieve green ones. The checklist should be considered at the stages of every business park design.

\section{DEVELOPMENT OF OFFICE BUILDINGS AND SKYSCRAPERS}

Office buildings, as we know them today, first appeared more than 100 years ago [2]. The massive population and large urbanization have created an increasing demand for tall buildings [3]. Skyscrapers were originally created in USA as a symbol of economic power and increasing worldwide business operations [3]. In the 1860s-1870s, the development of office buildings was mainly influenced by technology. In 1871, after the fire destroyed Chicago's core area, many new structures were built using the latest technology. The 16-story Monadnock masonry building was the tallest one in Chicago. Steel construction was introduced as a structural element in Chicago to help solve the masonry or material construction problem. In the $1880 \mathrm{~s}$, the use of the new construction techniques opened the door to a marvellous growth in the mass and number of office buildings. In most cities, office buildings were constructed in the downtown area, which allowed owners to locate their offices near transit lines, close to clients, and provide convenience for visitors and employees which lead to office buildings' concentration in city centres. The 10-story Home Insurance Building, built in Chicago in 1885, was generally considered to be the world's first skyscraper [4]. In the 1920s, the office construction boom reached its peak. During the depression period of the 1930s and World War II, office building development was limited [2]. However, between 1930 and 1931, two of the highest buildings in the world were constructed in New York City: the 77-story Chrysler Building and the 102- story Empire State Building [4]. By the beginning of the 1950s, new office structures were again under construction, and the downtown areas continued to be the main office space location. In the 1960s, suburban communities began to encourage office designers to build in outlying areas. By the mid-1960s, industrial and office parks appeared along highways. During that time, floor plates and building sizes continued to increase [2]. In the early $1970 \mathrm{~s}$, the 110 -story Twin Towers of the New York World Trade Center (WTC) were built [4]. In the 1980s, the improved technology fuelled the expansion of business and many new office buildings were wired for advanced technology applications. Technology increased employee's productivity and permitted some tenants to think about staff and space reduction [2].

\subsection{Impacts of skyscrapers on the environment and human well-being}

In order to make the best use of the land, tall buildings have negative impacts on the environment and citizens [5]. The density of tall buildings in city centers causes concentrated heat generation because of the high-density land use that contributes to the growth of the urban heat island, where high-rising buildings increase urban temperature and decrease evaporation. Temperatures of the centers of urban areas in huge cities are usually about $2^{\circ} \mathrm{C}-10^{\circ} \mathrm{C}$ higher than that in the countryside suburbs [6]. The huge skyscrapers, which are constructed mainly with a glass façade, are extreme wasters of high energy. The construction and materials of the modern box skyscraper, in addition to its actual every day running have negative effects on the environment. The taller the skyscraper, the extra energy it takes to operate its operational systems. The typical box skyscraper is often designed with poor thermal performance and without the use of natural air ventilation systems. They are usually 
too warm in summer and too cold in winter. HVAC units are regularly installed in the buildings for people to feel comfortable within. Such HVAC systems need a massive amount of energy to run [7]. High-rising buildings increase air pollution in the large urban areas because of the change in wind direction [5]. They cause undesirable amplification of wind flow in urban streets and open spaces [6]. On the other hand, they can also have the ability to reduce and filter wind stream in urban spaces [5]. A person can lose his physical and psychological sense of safety and security while working in high-rise buildings away from natural surrounding [6]. Vertical gated community syndrome decreases interaction and relationship between employees, and causes social exclusion [8].

\section{BUSINESS PARK TREND FOR SUSTAINABLE CITIES}

Sustainability is the act of meeting the requirements of today, without compromising the ability of the upcoming generations to meet their own needs [7]. Sustainability takes into consideration the social dimension, as well as ecological integrity and economic efficiency [9]. A business park is an area of land specially designated and landscaped to accommodate business offices, warehouses and light industrial corporations grouped together [10]. The distinguishing feature of the green building is its low-energy consumption and use of renewable resources like solar energy for electricity and heating instead of fossil fuels [6]. So, sustainability is not an end target, but a journey that business park can take to improve its economical, ecological and social conditions [10].

\subsection{Advantages of business parks}

There is a considerable difference between office environments that are simply not harmful and the positive environments that support health and well-being, and encourage productivity [10]. Designing comprehensive, mixed-use communities with appropriate access to employment, education, shopping, recreational opportunities, and health care will help reduce car tours and promote a healthier and more active lifestyle [11]. Green business parks are a natural and logical extension of green buildings. These parks, by their nature, help to protect the quality of life in the community [12]. The contact with nature can contribute to the physical and spiritual well-being of persons [11]. In addition to lower rates of heart and respiratory diseases, as a result of the reduced pollution, another potential benefit is a more active life and work style. Indirect health benefits include reduced commuting time, less stress, less noise, less cost, higher income and less social isolation [12]. Green business parks can reduce what is often thought of as a 'conflict' between the economy and the environment. Table 1 summarizes the main benefits of green business parks according to the 3 main pillars of sustainability.

\subsection{Worldwide examples of green business parks}

Many attempts have achieved the concept of green business parks all over the world. Table 2 states the main purposes and the design strategies of different worldwide cases [11]-[18].

\section{AN EVALUATIVE METHODOLOGY FOR SUSTAINABLE DESIGN OF GREEN BUSINESS PARKS IN EGYPT}

The paper sets the main influencing elements for designing green business parks considering the previous theoretical studies and the certified worldwide experiences. The checklist is applied to 3 Egyptian business parks (as it will be shown later) to reach the actual standards of the latest business parks. 
Table 1: Benefits of business parks [12], [13].

\begin{tabular}{|c|c|c|}
\hline Environmental & Social & Economical \\
\hline $\begin{array}{l}\text { Reduce energy resource } \\
\text { consumption, raw materials }\end{array}$ & $\begin{array}{l}\text { Show social and } \\
\text { environmental commitment }\end{array}$ & $\begin{array}{l}\text { Reduce operational, production and } \\
\text { disposal costs }\end{array}$ \\
\hline Healthier working environment & Attract talent & $\begin{array}{l}\text { Avoid environmental taxes and } \\
\text { penalties }\end{array}$ \\
\hline Increase energy independence & Promote local employment & Business efficiencies \\
\hline $\begin{array}{l}\text { Recycling, revalorization, elimination } \\
\text { of waste products }\end{array}$ & $\begin{array}{l}\text { Image of responsible and } \\
\text { sustainable company }\end{array}$ & $\begin{array}{l}\text { Innovative and sustainable } \\
\text { investments can be financially } \\
\text { supported }\end{array}$ \\
\hline $\begin{array}{l}\text { Reduction of emissions of greenhouse } \\
\text { gasses and other polluting gasses and } \\
\text { substances }\end{array}$ & $\begin{array}{l}\text { Expand local business } \\
\text { opportunities }\end{array}$ & $\begin{array}{l}\text { For a large number of sustainable } \\
\text { technologies, investments are paid } \\
\text { back even in the short term }\end{array}$ \\
\hline $\begin{array}{l}\text { Protection of the local environment } \\
\text { via site design }\end{array}$ & Partnership with businesses & Excess energy as export product \\
\hline $\begin{array}{l}\text { Efficient movement of people and } \\
\text { goods }\end{array}$ & Good jobs, larger tax base & New initiatives possible \\
\hline $\begin{array}{l}\text { Efficient energy usage in operations } \\
\text { and reduced emissions }\end{array}$ & $\begin{array}{l}\text { Enhance quality of life in areas } \\
\text { near the development }\end{array}$ & Income from sale of by-products \\
\hline $\begin{array}{l}\text { Efficient water usage and protection } \\
\text { of freshwater resources }\end{array}$ & $\begin{array}{l}\text { Positive impact on employee } \\
\text { health }\end{array}$ & Positive impact on productivity \\
\hline Provision of reserves, tracks, etc. & Community pride & Enhance corporate image \\
\hline
\end{tabular}

Table 2: Sustainable design strategies of green business parks.

\begin{tabular}{|c|c|c|}
\hline Name & Main targets & Sustainable design strategies \\
\hline 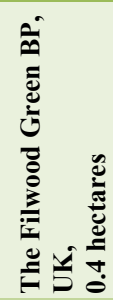 & $\begin{array}{l}\text { The park is designed to achieve a } \\
40 \% \mathrm{CO}_{2} \text { reduction and to save about } \\
46 \text { tons of } \mathrm{CO}_{2} \text { annually [15] }\end{array}$ & $\begin{array}{l}\text { - High-performance building materials } \\
\text { - Energy efficient services } \\
\text { - Widespread photovoltaic panels } \\
\text { - Low water usage purposes } \\
\text { - Green roofs } \\
\text { - Electric vehicles } \\
\text { - Native tree species } \\
\text { - Fully accessible work and meeting space }\end{array}$ \\
\hline 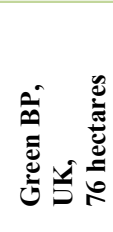 & $\begin{array}{l}\text { The project targets a BREEAM rating } \\
\text { of 'Excellent' [16]. It creates a } \\
\text { wildlife landscape, which helps in } \\
\text { creating a thriving business } \\
\text { community, as well as attracting new } \\
\text { occupiers to the park [17] }\end{array}$ & $\begin{array}{l}\text { - Native, local landscape } \\
\text { - Preserve biodiversity } \\
\text { - Wind turbines for electricity [18] } \\
\text { - High quality, sustainable workplace } \\
\text { - Use bicycles for internal transportation } \\
\text { - Connected to public transport [17] }\end{array}$ \\
\hline 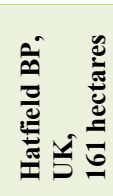 & $\begin{array}{l}\text { The park provides a fresh and a } \\
\text { modern business environment to } \\
\text { work in, visit and enjoy [19] }\end{array}$ & $\begin{array}{l}\text { - Large spaces with } 24 \mathrm{hr} \text { use and access } \\
\text { - Network of footpaths and cycleways } \\
\text { - Useful and convenient on-site amenities [19] }\end{array}$ \\
\hline 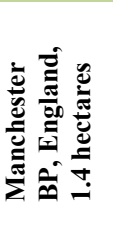 & $\begin{array}{l}\text { The park targets global business } \\
\text { connection. It targets BREEAM } \\
\text { "Excellent" certificate [19] }\end{array}$ & $\begin{array}{l}\text { - Solar hot water } \\
\text { - Green roofs } \\
\text { - Living walls } \\
\text { - Photovoltaic electricity generation } \\
\text { - Energy efficient cooling and heating system } \\
\text { - LED lighting }\end{array}$ \\
\hline
\end{tabular}


Table 2: Continued.

\begin{tabular}{|c|c|c|}
\hline Name & Main targets & Sustainable design strategies \\
\hline 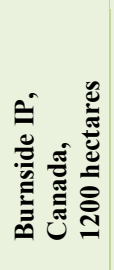 & $\begin{array}{l}\text { The park protects the property values } \\
\text { and enhances the investment of } \\
\text { businesses. It contributes to reducing } \\
\text { greenhouse gas emissions to } 20 \% \\
\text { [12] }\end{array}$ & $\begin{array}{l}\text { - An efficient business environment through } \\
\text { environmental management standards [12] } \\
\text { - Setting waste reduction plans } \\
\text { - Energy, water and materials conservation } \\
\text { plans } \\
\text { - Recovered, repaired, recycled and reused } \\
\text { materials }\end{array}$ \\
\hline 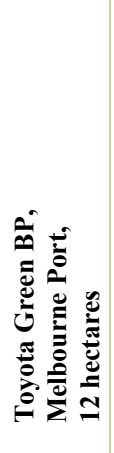 & $\begin{array}{l}\text { The park reduces the environmental } \\
\text { impact of the built environment } \\
\text { through a sustainable development } \\
\text { balanced plan to lower the day-to-day } \\
\text { running costs. It reduces the } \\
\text { greenhouse gas emissions by using } \\
\text { improved energy efficiency systems } \\
\text { [20] }\end{array}$ & $\begin{array}{l}\text { - Energy saving building lighting } \\
\text { - Natural ventilation, daylight maximized } \\
\text { - Maximize insulation and minimize air leakage } \\
\text { - Use bicycles for internal transportation } \\
\text { - Water efficient garden } \\
\text { - Waste management plan } \\
\text { - Recycling targets } \\
\text { - Building structure is precast panels and steel } \\
\text { which are prefabricated off site } \\
\text { - Durable and low maintenance materials } \\
\text { - Low VOC paints } \\
\text { - Reduced potable water use [20] }\end{array}$ \\
\hline 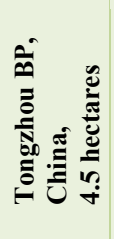 & $\begin{array}{l}\text { The park is built to be highly } \\
\text { international, energy saving and } \\
\text { environmentally protected low- } \\
\text { density business area }\end{array}$ & $\begin{array}{l}\text { - Utilizing solar, geothermal and other energy } \\
\text { systems to create energy-saving and } \\
\text { environmental protection planning which } \\
\text { covers the infrastructure facility design, } \\
\text { building construction material selection and } \\
\text { sustainable garbage treatment }\end{array}$ \\
\hline 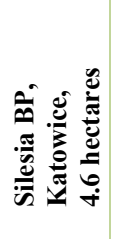 & $\begin{array}{l}\text { The park develops buildings using } \\
\text { energy efficient resources, which take } \\
\text { into account both environmental } \\
\text { concerns and user comfort [21] }\end{array}$ & $\begin{array}{l}\text { - Efficient use of resources } \\
\text { - Natural lighting } \\
\text { - Offices are designed to guarantee the effective } \\
\text { use of daylight } \\
\text { - 24-hour security and access control } \\
\text { - Environmentally friendly materials [21] }\end{array}$ \\
\hline 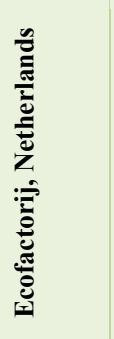 & $\begin{array}{l}\text { The park is considered as a large- } \\
\text { scale production and distribution } \\
\text { companies which promote } \\
\text { sustainability and carbon neutrality as } \\
\text { a primary objective [13] }\end{array}$ & $\begin{array}{l}\text { - Energy-efficient buildings } \\
\text { - Thermal salt panels and solar cells } \\
\text { - Private electricity grid connected to windmills } \\
\text { - Individual cold and heat storage systems [13] } \\
\text { - Re-use rain water for cleaning purposes } \\
\text { - Full use of daylight } \\
\text { - Production of renewable energy } \\
\text { (solar PV, biomass) [14] } \\
\text { - Use bicycles for internal transportation }\end{array}$ \\
\hline
\end{tabular}




\subsection{Business park evolution in Egypt}

Since 2000, business parks have appeared as a new office buildings' development in the Egyptian cities; they allow escaping from the crowd of the capital cities. They transfer some of the major business outside the central areas to provide a solution for the centralization problem in Capital cities.

1. Smart Village $(S V)$, on Alexandria desert road with a total plot area of 3 million $\mathrm{m}^{2}$, is a stress-free business environment, smart-mix of business and entertainment spaces, in addition to some other facilities including a nursery, school, club, restaurants, and clinic [22]. All buildings' facades are designed in neutral and unified white and blue colors which make a nice contrast with the vegetation. At least $60 \%$ of the facade area is covered by bluish tinted glass windows (Fig. 1) to invite the natural daylight [23]. LED technology has been adopted to provide energy efficient solutions [24].

The big Lake in SV acts as an open water reservoir for putting out a fire and irrigating the landscape [25]. A $60 \mathrm{KWs}$ solar power plant, connected to the electric grid, is installed to feed the large water pump station. SV plans to cover all its public car parks with solar panels to generate 3.6MW of electricity [23].

2. Cairo Business Park (CBP), in New Cairo with a total plot size of $75,615 \mathrm{~m}^{2}$, is considered to be a totally integrated business compound with a huge gulf area. The internal spaces are fully opened to the outside vegetation (Fig. 2). All the park offices are sound-proofed against the outside noise. The windows are installed in thermally treated double-glazed curtain walls to guarantee energy saving [26]. The center of the park is designed to be a place for socializing, breaks and a host of other activities. The employees are free to move without worrying about their security. The pedestrian walkways intersect with the foliage and the water features that surround the office buildings which help to minimize any potential noise, exhaust emissions or road accidents.

3. Capital Business Park (CBP) is located in Al Sheikh Zayed City, west of Cairo, with a total plot area of $35,000 \mathrm{~m}^{2}$. Each office building is designed to accommodate the requirements of hosting high-level corporate and business. The offices are equipped with the latest technological products to provide potential solutions that will allow the workers to work best [27]. The center space contains cafes that contribute to the recreational and leisure lifestyle of the park (Fig. 3).

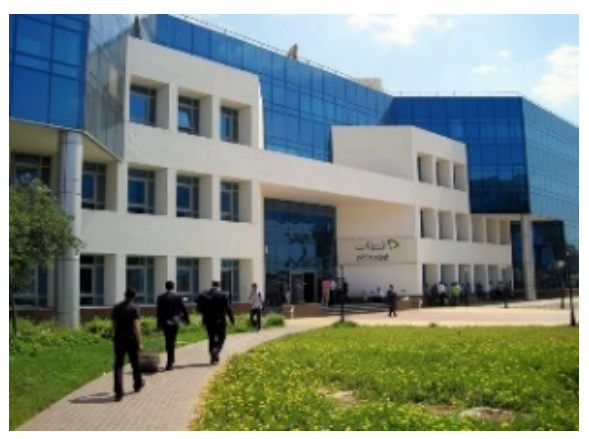

Figure 1: Bluish tinted glass windows permit natural daylight. (Source: http://www.bitunil.com)

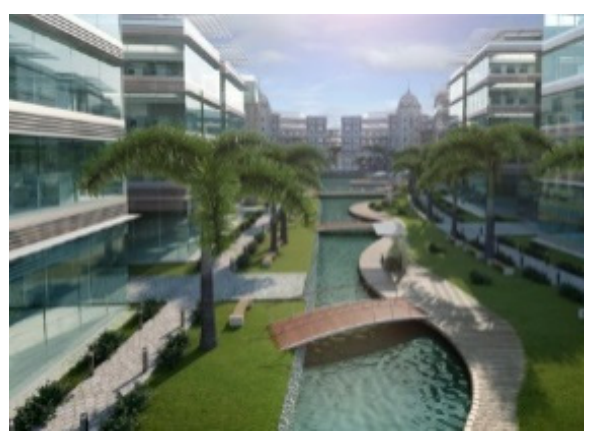

Figure 2: Integration between buildings and landscaped areas. (Source: http://www.cairobusinesspark.com) 


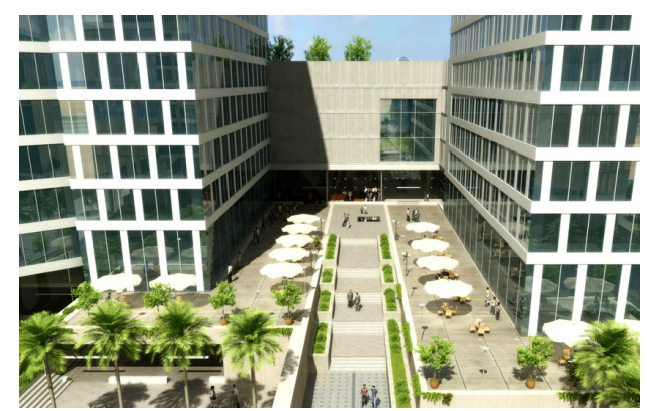

Figure 3: Integration between business and recreational areas. (Source: http://www.profilerz.com)

\subsection{The methodology of the evaluation checklist}

The paper follows the relative weights method to evaluate the sustainability degree of business parks. we assume the equal importance of each indicator of the sustainable design aspects. A checklist is concluded to show the evaluation items with scores applied on case studies in Egypt. The way of evaluation is qualitative from the researchers' background study and observation, we will give (1) point to the existed indicator and (0) point to the un-existed one. It will reach the total points achieved by each element of evaluation items. Then it will calculate the percentage achieved by each park to conclude whether it is a successful evaluation or needs some recommendations for redesign or upgrading plans as shown in Fig. 4.

\subsection{The checklist of sustainable design strategies of green business parks}

Based on several authors (see [9], [12], [28]-[31]) that discuss the different elements and indicators of business park's designs at different locations, the paper sets the following checklist of the sustainable design guidelines towards green business parks in Egypt (Table 3).

\section{RESULTS AND CONCLUSION}

Office tall buildings are not compatible with the environmental, social and economic dimensions of sustainability so that they do not contribute significantly to the sustainable development. The evolution of green business parks into ecological systems is still at an early stage. Although some research and design projects have tried to set the essential sustainable strategies of green business parks, there is no clear comprehensive framework to work on. The paper aims to improve the environmental performance of the existing business parks, particularly in Egypt. It puts some principal sustainable design guidelines so as to be tackled in all design stages of green business parks. The previous checklist shows that the satisfied range of sustainability indicators in SV is (57\%), Cairo BP is (69\%) and Capital BP is (64\%). $\mathrm{SV}$ and Capital BP need redesign plans from an environmental point of view, while Cairo BP needs upgrading plan to meet sustainability standards.

Fig. 5 shows that the weakness points of the selected business parks in Egypt are: non-conservation of the natural environment, unsustainable landscape design strategy, irrational waste management, energy consuming and usage of non-recyclable materials. The paper recommends that the actual business parks need redesign plans which can be tackled through the sustainable design strategies that have been set previously. 


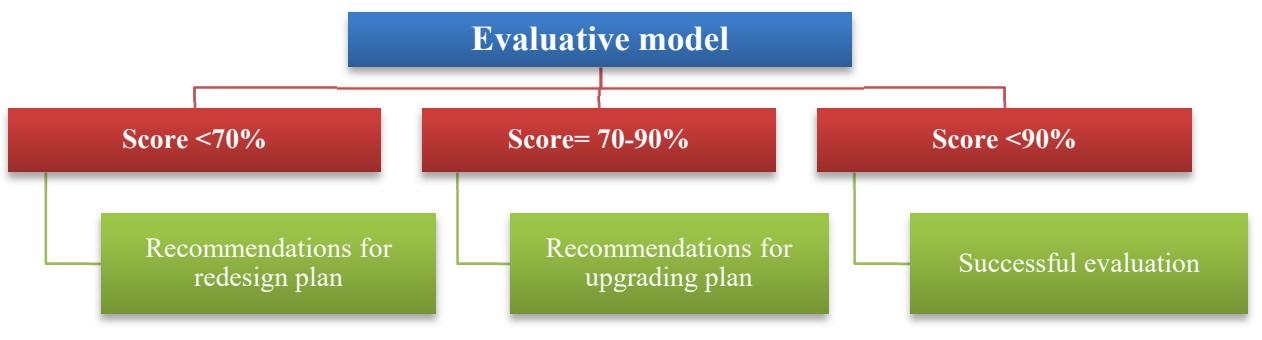

Figure 4: Evaluation of results of the checklist applied to the case study.

Table 3: The checklist of sustainable design strategies of green business parks.

\begin{tabular}{|c|c|c|c|c|c|c|c|}
\hline \multirow{2}{*}{ 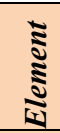 } & \multirow{2}{*}{ Indicators } & \multirow[b]{2}{*}{ 氙 } & \multirow[b]{2}{*}{ 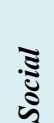 } & \multirow{2}{*}{$\frac{\sqrt{3}}{3}$} & \multicolumn{3}{|c|}{ Egyptian BP } \\
\hline & & & & & (1) & (2) & (3) \\
\hline \multirow{3}{*}{ 咅 } & $\begin{array}{l}\text { Prepare a long-term 'master plan' be able to control } \\
\text { and adapt the environment }\end{array}$ & $\sqrt{ }$ & $\sqrt{ }$ & $x$ & 1 & 0 & 0 \\
\hline & Compliance with environmental regulations & $\sqrt{ }$ & $\sqrt{ }$ & $x$ & 1 & 1 & 1 \\
\hline & $\begin{array}{l}\text { Minimize energy demand for the site through } \\
\text { orientation and maximizing passive solar gain }\end{array}$ & $\sqrt{ }$ & $\sqrt{ }$ & $\sqrt{ }$ & 1 & 1 & 0 \\
\hline \multirow{10}{*}{ 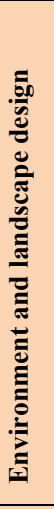 } & $\begin{array}{l}\text { Implement a public awareness program concerning } \\
\text { natural environmental conservation }\end{array}$ & $\sqrt{ }$ & $\sqrt{ }$ & $\sqrt{ }$ & 0 & 0 & 0 \\
\hline & $\begin{array}{l}\text { Establish an environmentally - friendly landscaping } \\
\text { plan }\end{array}$ & $\sqrt{ }$ & $\sqrt{ }$ & $x$ & 1 & 0 & 0 \\
\hline & $\begin{array}{l}\text { Implement a plan for natural flora and fauna to } \\
\text { maintain the ecological balance of the site }\end{array}$ & $\sqrt{ }$ & $x$ & $x$ & 0 & 0 & 0 \\
\hline & Use of deciduous plantings for shading purposes & $\sqrt{ }$ & $\sqrt{ }$ & $\times$ & 0 & 1 & 1 \\
\hline & Reduce landscape maintenance labor & $x$ & $x$ & $\sqrt{ }$ & 0 & 1 & 1 \\
\hline & Use local and adaptive plants & $\sqrt{ }$ & $x$ & $\sqrt{ }$ & 0 & 0 & 0 \\
\hline & Plant wide green areas for air purification and & $\sqrt{ }$ & $\sqrt{ }$ & $x$ & 1 & 1 & 0 \\
\hline & Use highly durable landscape elements & $\sqrt{ }$ & $x$ & $x$ & 0 & 1 & 1 \\
\hline & Use plants need less maintenance & $\sqrt{ }$ & $x$ & $\sqrt{ }$ & 0 & 0 & 0 \\
\hline & Replant existing trees or plants in site & $\sqrt{ }$ & $x$ & $\sqrt{ }$ & 0 & 0 & 0 \\
\hline \multirow{5}{*}{$\frac{\overline{\tilde{\nu}}}{\bar{\omega}}$} & Design water flows to conserve resources & $\sqrt{ }$ & $x$ & $\sqrt{ }$ & 1 & 1 & 1 \\
\hline & Collect rainwater for re-use & $\sqrt{ }$ & $x$ & $\sqrt{ }$ & 1 & 0 & 0 \\
\hline & Use irrigation systems for water rationalization & $\sqrt{ }$ & $x$ & $\sqrt{ }$ & 1 & 1 & 1 \\
\hline & $\begin{array}{l}\text { Where landscape Irrigation is required, systems are } \\
\text { to be automated (rain-shutoff, time-clock } \\
\text { automated) and integrated with rainwater }\end{array}$ & $\sqrt{ }$ & $x$ & $x$ & 1 & 0 & 0 \\
\hline & Use gray water for irrigation & $\sqrt{ }$ & $x$ & $\sqrt{ }$ & 1 & 1 & 1 \\
\hline \multirow{4}{*}{ 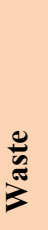 } & Establish a plan for solid waste management & $\sqrt{ }$ & $x$ & $x$ & 0 & 0 & 0 \\
\hline & $\begin{array}{l}\text { Reduce toxic materials risks through integrated } \\
\text { site-level waste treatment }\end{array}$ & $\sqrt{ }$ & $x$ & $x$ & 1 & 1 & 1 \\
\hline & $\begin{array}{l}\text { Use wastes as potential products to be reused } \\
\text { within the park or marketed to someone else }\end{array}$ & $\sqrt{ }$ & $x$ & $\sqrt{ }$ & 0 & 0 & 0 \\
\hline & Using separate trash receptacles & $\sqrt{ }$ & $x$ & $\times$ & 0 & 1 & 1 \\
\hline
\end{tabular}


Table 3: Continued.

\begin{tabular}{|c|c|c|c|c|c|c|c|}
\hline \multirow[b]{2}{*}{$\frac{\sqrt{2}}{\sqrt[3]{2}}$} & \multirow[b]{2}{*}{ Indicators } & \multirow[b]{2}{*}{ 文 } & \multirow[b]{2}{*}{ 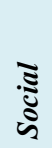 } & \multirow[b]{2}{*}{ 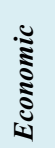 } & \multicolumn{3}{|c|}{ Egyptian BP } \\
\hline & & & & & (1) & (2) & (3) \\
\hline \multirow{10}{*}{ 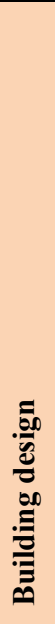 } & Design for green buildings concepts & $\sqrt{ }$ & $\sqrt{ }$ & $x$ & 1 & 1 & 1 \\
\hline & Design a building in the right location & $\sqrt{ }$ & $x$ & $\sqrt{ }$ & 0 & 1 & 1 \\
\hline & Integrate workplace with recreation areas & $\sqrt{ }$ & $\sqrt{ }$ & $x$ & 1 & 1 & 1 \\
\hline & $\begin{array}{l}\text { Maximize the thermal efficiency of individual } \\
\text { buildings through insulation, natural shelter, and } \\
\text { appropriate glazing }\end{array}$ & $\sqrt{ }$ & $\sqrt{ }$ & $\times$ & 1 & 1 & 1 \\
\hline & $\begin{array}{l}\text { Design high quality, flexible space to attract } \\
\text { workers }\end{array}$ & $\times$ & $\sqrt{ }$ & $x$ & 0 & 1 & 1 \\
\hline & Optimize winter solar gain/summer shading & $\sqrt{ }$ & $\sqrt{ }$ & $x$ & 0 & 1 & 1 \\
\hline & $\begin{array}{l}\text { Employ use of natural light to minimize artificial } \\
\text { lighting }\end{array}$ & $\sqrt{ }$ & $\sqrt{ }$ & $\sqrt{ }$ & 1 & 1 & 1 \\
\hline & $\begin{array}{l}\text { Use LED technology for all lighting including } \\
\text { external and car park lighting }\end{array}$ & $\sqrt{ }$ & $x$ & $x$ & 1 & 1 & 1 \\
\hline & $\begin{array}{l}\text { Use local indigenous green roofs/walls to enhance } \\
\text { overall passive design strategy }\end{array}$ & $\sqrt{ }$ & $\sqrt{ }$ & $x$ & 0 & 0 & 0 \\
\hline & Manage noise pollution & $x$ & $\sqrt{ }$ & $x$ & 0 & 1 & 1 \\
\hline \multirow{6}{*}{ 家 } & Establish an energy management plan for the site & $\sqrt{ }$ & $x$ & $\times$ & 1 & 0 & 0 \\
\hline & Maximize energy efficiency through facility design & $\sqrt{ }$ & $\times$ & $x$ & 0 & 1 & 1 \\
\hline & Investigate alternative energy sources & $\sqrt{ }$ & $x$ & $x$ & 1 & 0 & 0 \\
\hline & Use renewable sources extensively & $\sqrt{ }$ & $x$ & $x$ & 1 & 0 & 0 \\
\hline & $\begin{array}{l}\text { Minimise demand for water heating, space heating } \\
\text { and cooling, lighting, and power through efficient } \\
\text { equipment and controls }\end{array}$ & $\sqrt{ }$ & $\times$ & $x$ & 0 & 0 & 0 \\
\hline & Use equipment with fewer emissions & $\sqrt{ }$ & $\sqrt{ }$ & $x$ & 0 & 1 & 0 \\
\hline \multirow{3}{*}{ 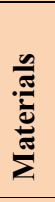 } & $\begin{array}{l}\text { Ensure maximum re-using and recycling of } \\
\text { materials }\end{array}$ & $\sqrt{ }$ & $x$ & $x$ & 0 & 0 & 0 \\
\hline & $\begin{array}{l}\text { Create space for sorting and storing recyclable } \\
\text { materials }\end{array}$ & $\sqrt{ }$ & $x$ & $\times$ & 0 & 0 & 0 \\
\hline & Use local materials & $\sqrt{ }$ & $x$ & $\sqrt{ }$ & 0 & 1 & 1 \\
\hline \multirow{9}{*}{ 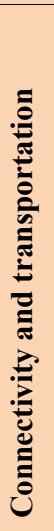 } & Implement high telecommunication services & $x$ & $\sqrt{ }$ & $x$ & 1 & 1 & 1 \\
\hline & Share environmental information systems & $\sqrt{ }$ & $\sqrt{ }$ & $x$ & 0 & 1 & 1 \\
\hline & Share commuting, share shipping & $x$ & $\sqrt{ }$ & $x$ & 1 & 1 & 1 \\
\hline & $\begin{array}{l}\text { Transportation must be capable of dealing with the } \\
\text { movement of goods and people within - and to and } \\
\text { from - the park }\end{array}$ & $\times$ & $\sqrt{ }$ & $\sqrt{ }$ & 1 & 1 & 1 \\
\hline & $\begin{array}{l}\text { Provide public transportation and facilities for } \\
\text { walking and cycling }\end{array}$ & $\sqrt{ }$ & $\sqrt{ }$ & $\sqrt{ }$ & 0 & 1 & 1 \\
\hline & $\begin{array}{l}\text { Create sustainable modes of transport and move away } \\
\text { from sole reliance on cars }\end{array}$ & $\sqrt{ }$ & $\sqrt{ }$ & $\sqrt{ }$ & 0 & 1 & 1 \\
\hline & The supply of car parking & $x$ & $\sqrt{ }$ & $x$ & 1 & 1 & 1 \\
\hline & $\begin{array}{l}\text { Common vehicle maintenance, intra-park } \\
\text { transportation }\end{array}$ & $x$ & $\sqrt{ }$ & $x$ & 1 & 1 & 1 \\
\hline & Accident prevention, emergency response & $\times$ & $\sqrt{ }$ & $\sqrt{ }$ & 1 & 1 & 1 \\
\hline
\end{tabular}


Table 3: Continued.

\begin{tabular}{|c|c|c|c|c|c|c|c|}
\hline \multirow{2}{*}{ 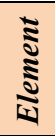 } & \multirow{2}{*}{ Indicators } & \multirow[b]{2}{*}{ 今ે } & \multirow{2}{*}{ 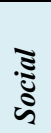 } & \multirow{2}{*}{ 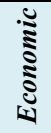 } & \multicolumn{3}{|c|}{ Egyptian BP } \\
\hline & & & & & (1) & (2) & (3) \\
\hline \multirow{5}{*}{ 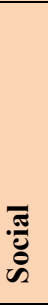 } & $\begin{array}{l}\text { Create high-quality sustainable workplaces which } \\
\text { support the corporate productivity agenda }\end{array}$ & $\sqrt{ }$ & $\sqrt{ }$ & $x$ & 1 & 1 & 1 \\
\hline & $\begin{array}{l}\text { Create an environment which provides a place that } \\
\text { attracts wide scale of visitors }\end{array}$ & $\sqrt{ }$ & $\sqrt{ }$ & $x$ & 1 & 1 & 1 \\
\hline & Create places that help improving health & $\sqrt{ }$ & $\sqrt{ }$ & $x$ & 1 & 1 & 1 \\
\hline & Design safe and private spaces & $x$ & $\sqrt{ }$ & $x$ & 1 & 1 & 1 \\
\hline & $\begin{array}{l}\text { Create variety of social activities which respond to } \\
\text { community needs }\end{array}$ & $x$ & $\sqrt{ }$ & $x$ & 1 & 1 & 1 \\
\hline \multirow[b]{3}{*}{ 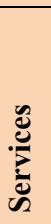 } & $\begin{array}{l}\text { Create large scale areas to accommodate high-quality } \\
\text { amenities and services }\end{array}$ & $x$ & $\sqrt{ }$ & $x$ & 1 & 1 & 1 \\
\hline & Provide a variety of recreational uses & $\sqrt{ }$ & $\sqrt{ }$ & $\times$ & 1 & 1 & 1 \\
\hline & $\begin{array}{l}\text { Presence of cafés, bars, stores, gyms, schools and } \\
\text { doctors helps to create a sustainable community }\end{array}$ & $x$ & $\sqrt{ }$ & $x$ & 1 & 1 & 1 \\
\hline \multicolumn{5}{|c|}{ Total (58 points) } & 33 & 40 & 37 \\
\hline
\end{tabular}

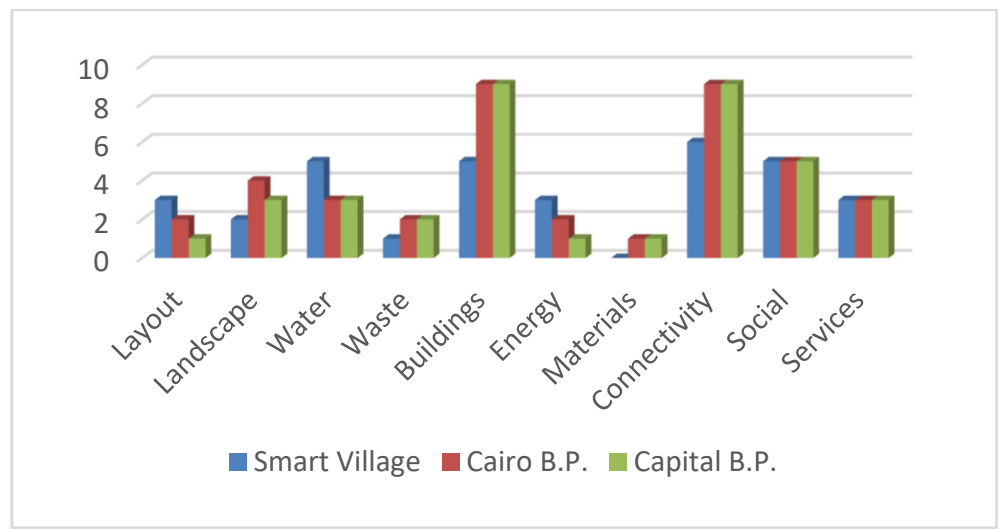

Figure 5: Comparing the results of the sustainable design techniques.

\section{ACKNOWLEDGEMENT}

The first author would like to thank the Egyptian Ministry of Higher Education (MoHE) for providing the financial support (Ph.D. scholarship) for this research, as well as the EgyptJapan University of Science and Technology (E-JUST) for offering the facility and tools needed to conduct this work.

\section{REFERENCES}

[1] Gelil, I.A., Energy demand profile in Arab Countries, 2015.

[2] Mason, G., The evolution of office building research. 157, 1997.

[3] Formaneck, S.D., Skyscrapers and economic strategy and development: the case of Bahrain's proposed Murjan tower. 1(4), 2013. 
[4] Black, F. \& Challinger, D., High-rise building definition, development, and use. Aug. 2005.

[5] Hayati, H. \& Sayadi, M.H., Impact of tall buildings in environmental pollution. Environmental Skeptics and Critis 1(1), pp. 8-11, 2012.

[6] Aldeberky, A.A., The influence of high-rise buildings on the environment. 2010.

[7] WritePass, How Skyscrapers affect the environment. 2012.

[8] Mnitp, A. \& Adedoyin, O., Impact of Skyscrapers in urban area: Case study of Lagos Island, Lagos State, Nigeria, pp. 1-31, 2009.

[9] Co, R.P., Designing eco-industrial parks: a synthesis of some experiences. 6, pp. 181$188,1998$.

[10] AMRP, Sustainable business parks (Strategies and actions), 2012.

[11] Stone, D., Health and nature: the sustainable option for healthy cities. Aug. 2016.

[12] Stewart, G., Green Buildings \& Green Business Parks - Striving for Sustainability Through Design and Operations, Priority One, Environment Bay of Plenty \& AQUAS Consultants Ltd.: New Zealand, 2007.

[13] Timmerman, J., Deckmyn, C., Vandevelde, L. \& Van Eetvelde, G., Low carbon business park manual: a guide for developing and managing energy efficient and low carbon businesses and business parks, UK, 2014.

[14] Sparkling Projects, Sustainability measures Ecofactorij Minimum environmental impact of the business park, 2012.

[15] Filwood Business Park, Online. www.filwoodgreen.co.uk/. Accessed on: 18 Aug. 2016.

[16] GreenPark, Online. www.greenpark.co.uk/. Accessed on 15 Nov. 2016.

[17] Hynes, J., Clark, E. \& Jones, A., Green park, park life, 2015.

[18] OMERS, New HUAWEI UK HeadQuarters to be located at Green Park Reading. Oct. 2012, pp. 1-3, 2013.

[19] Goodman Real Estate Adviser, Hatfield Business Park, UK, 2008.

[20] MAB \& Folkestone, Toyota green Business Park Port Melbourne, A case study of Environmental Initiatives, Nov. 2006.

[21] Skanska Property Poland Sp. z.o.o., Skanska Silesia Business Park, Poland, 2014.

[22] Magdy, H., Public participation in urban development process through information and communication technologies, Ain Shams University, Cairo, Egypt, 2010.

[23] Ghafar, A.A., Smart Villages Co. Egypt Premier Technology \& Business Parks Developers and Managers, Egypt, 2015.

[24] SV Community News, Smart Village celebrates 10 years of Quantum Leaping. The Village Community News, Egypt, Jan.-Mar. 2015.

[25] Smart Village, Online. www.smart-villages.com/. Accessed on: 16 Nov. 2016.

[26] Misr Italia, Cairo Business Park, Online. www.cairo-businesspark.com/. Accessed on: 2 Nov. 2016.

[27] Dorra Group, Online. http://www.dorra.com/portfolio-item/capital-business-park/. Accessed on: 7 Nov. 2016.

[28] Jones Lang LaSalle, The new geography of office demand 2: Business Parks rising to the challenge. JIL, Sep. 2014.

[29] CNPA, Sustainable Design Guide: Supplementary Planning Guidance, Oct. Cairngorms National Park Authority, 2010.

[30] Wyndham, Environmentally Sustainable Design Framework, 2012.

[31] Atwa, S., Contemporary trends in landscape design at urban parks, SCU, Ismailia, Egypt, 2015. 